\title{
THE EFFECT OF VARIATIONS OF LEAD METAL SOLUTIONS ON THE ADSORBENT OF PALEMBANG MUD WASTE WASTE TIRTA MUSI PALEMBANG
}

\author{
Netty Herawati ${ }^{1}$, Muhammad Rafiqy ${ }^{1}$, Kiagus Ahmad Roni ${ }^{1}$, Heni Juniar ${ }^{1}$ \\ ${ }^{1}$ Chemical Engineering, University of Muhammadiyah Palembang, Indonesia \\ Email: ${ }^{1}$ Nettyherawati76@gmail.com, muhammadrafiqy@gmail.com, kiagusaroni@gmail.com, \\ henijuniar02@gmail.com,
}

\begin{abstract}
Abstarct
Industrial waste can cause environmental pollution, one of which is heavy metal waste in the form of lead. Lead is a dangerous and toxic heavy metal that can cause damage to the surrounding environment. Liquid waste containing lead metal in industry contains a mixture of other chemical compounds, causing the $\mathrm{pH}$ of the solution in the waste to vary.

The level of lead metal waste needs to be reduced so that it does not disturb the ecosystem in the surrounding environment. To reduce the levels of lead metal waste, it can be done by an absorption or adsorption process. The adsorption process uses an adsorbent in the form of PDAM sludge which is activated so that it becomes activated sludge. To enlarge the pores, the adsorbent will be activated using a 2 $\mathrm{M} \mathrm{KOH}$ solution with a 2:1 ratio between the solution and the sewage sludge. The selected adsorbent is the sewage sludge of PDAM Tirta Musi Palembang which contains PAC (Poly Aluminum Chloride) which can help optimize absorption. By varying the $\mathrm{pH}$ of the lead metal solution, namely 3,4,5,6 and 7. The level of metal degradation was analyzed using AAS with 4 absorption parameters with an absorption capacity of $23.22 \mathrm{mg} / \mathrm{g}$.
\end{abstract}

Key words : Lead metal waste, $\mathrm{pH}$ variation, adsorbent.

\section{INTRODUCTION}

Economic growth is increasing every year, causing development and increasing industry. This is welcomed to improve the quality of life but has another impact, namely waste disposal from industry which can cause environmental pollution. Liquid waste from industrial waste if not monitored closely enough can cause pollution such as heavy metal waste. Heavy metal waste such as $\mathrm{Hg}, \mathrm{Fe}, \mathrm{Ni}$ and one of the most common

ones is lead. Lead is a toxic heavy metal that can also have an impact on the environment and can cause poisoning if it is contaminated with living things. Not only can be contaminated with the surrounding environment, heavy metals from a contaminated environment in the form of fish in rivers and then 
consumed by humans can cause health effects for humans depending on the level of heavy metals bound in the body. The toxic power possessed will work as a barrier to enzyme work, so that the body's metabolic process is interrupted (Fauziah, 2019).

Waste from processing by-products from industry is usually disposed of in the amount regulated in the Regional Regulation on the environment directly to the environment around the industry, usually directly to the river, where waste containing heavy metals even in small amounts accumulates and causes pollution to the environment. Lead mixed with other substances from processing products in industry can make a mixture that still contains lead heavy metal but has a varying $\mathrm{pH}$ in the form of an acidic lead mixture $\mathrm{pH}$ or the same $\mathrm{pH}$ as lead heavy metal solution. This is because the mixing of metal waste with industrial raw materials results in the mixing of liquid waste to produce liquid waste with various $\mathrm{pH}$ variations.

Several studies have conducted experiments to reduce liquid waste in the form of lead metal such as ion exchange, chemical precipitation, neutralization, electrochemical reduction, electrodialysis methods, reverse osmosis, solvent extraction, and adsorption (Dabrowski and Erdem et al, 2004). Of these several methods, adsorption is one method that can be used effectively because this method is simpler to treat raw water and wastewater.

In a research journal conducted by Darmayanti et al (2012) regarding the adsorption of lead (Pb) and zinc $(\mathrm{Zn})$ from the solution using Biocharcoal (Biocharcoal) Banana Peel Kepok Based on pH Variations with $\mathrm{pH}$ variations ranging from 3,4,5,6 and 7 it was concluded that $\mathrm{pH} 4$ had the highest absorption of $19.40 \mathrm{mg} / \mathrm{g}$. Thus, adsorption is considered effective for the absorption of lead metal in water treatment.

The energy on the surface and the attractive forces on the surface of the adsorbent can cause adsorption to occur. The properties of different adsorbent surfaces depend on the arrangement in the molecules of the substance surrounded by other molecules so that the attractive forces between molecules will be equal, balanced in all parts. Meanwhile, molecules on the surface only have an inward attractive force (Hajar, 2016).

According to Widayatno et al (2017), the factors that influence the adsorption are types of adsorbents, namely polar, non-polar and alkaline adsorbents, kinds of adsorbates, concentration of each substance, surface area, pressure, solubility of the adsorbent, coadsorption and stirring. .

If the adsorption process is in the form of absorption, it will be combined with the sedimentation process of chemicals when the two methods are combined, it can have a maximum effect on absorption. Chemical precipitation using aluminum sulfate makes the particles separate from the water in the wastewater, thus requiring further selection of adsorption materials. One of the waste products that contains aluminum sulfate and can also be used as an adsorbent for further processes is the waste product 
from PDAM production which contains aluminum sulfate which is only disposed of after the process of purifying clean water from raw material for river water and water from the surrounding environment. The increase in water production from PDAMs due to the increasing population density in the city has resulted in the productivity of the PDAM industry increasing. This increase in production also results in an increase in by-products produced by PDAMs. So, it is necessary to have a further method of handling the waste produced by PDAM in the form of PDAM mud.

According to Said (2018) the clean water treatment system on the technology used by PDAM is still conventional, namely the coagulation-flocculation system, sedimentation, fast sand filter, and disinfection. The results of this conventional process will only be taken from clean water and waste in the form of sludge from the process will be discharged directly into the environment. The sedimentation process is usually a continuation of the two coagulation processes in which the raw water is added with coagulant such as alum and PAC (Poly Aluminum Chloride) so that the composition of this mud is not only dense but also contains alum, lime, ferric chloride and a little humus.

PDAM mud also has a large surface area and has high reactivity so that PDAM mud has the potential to be used as an adsorbent (Hadi et al, 2015). According to Nenny et al (2013) Solid waste from mud can be used to adsorb hazardous metals in the form of liquid waste from industrial by-products. This is due to the remaining chemical substances in the form of alum, as well as PAC in the sludge produced by PDAM waste.

PDAM mud has the potential as waste and has a negative impact on human health and the environment if it is recycled or reused (Hadi et al, 2015). The potential of this waste can be positive by doing special treatment to the sample product produced by PDAM. PDAM sludge is converted into an active adsorbent so that it can be used to absorb ions in industrial waste in the form of heavy metal ions such as lead metal.

In the manufacture of activated sludge adsorbents, chemical activation is used where the activator can affect the pore structure, functional groups and metal adsorption performance (Jin \& Trakal, 2014). Chemical activators commonly used are $\mathrm{ZnCl}$, $\mathrm{NaOH}, \mathrm{KOH}, \mathrm{H} 2 \mathrm{SO} 4$ and $\mathrm{H} 3 \mathrm{PO} 4$ (Hadi et al., 2015). The activator used in the form of $\mathrm{KOH}$ as a strong base activator which has the potential to expand the pores of the sludge waste getting bigger and bigger.

According to Apriani et al (2013) in Lestari (2013) the research he has done with the manufacture of an adsorbent made from durian skin using a $\mathrm{KOH}$ activator showed that this activation can enlarge the pores of the adsorbent with a $\mathrm{KOH}$ concentration of $25 \%$ which can reduce the concentration of $\mathrm{Fe}$ metal by $85,38 \%$.

Pan (2011) reported that adsorbents made from chemically activated sludge have a higher surface area and pollutant adsorption capacity than biologically activated sludge. Chemically activated sludge differs 
from biological sludge, which results from the chemical deposition of wastewater with a coagulant. The presence of coagulants and their by-products in the chemically activated sludge material can affect the texture properties of the sludge adsorbent and the absorption of the resulting contaminants (Pan in Xu, 2015).

The adsorbent from industrial activated sludge solid waste crumb rubber on the absorption of $\mathrm{Cr}$ metal research conducted by Nenny et al (2013) using variations in particle size (40-60, 60-80, 80-100 and 100 mesh) and contact time (15, 30,60 and 120 minutes) showed that activated sludge solid waste can be used for $\mathrm{Cr}$ metal absorption with the highest absorption efficiency of particle size 60-80 mesh and contact time of 60 minutes of $98.97 \%$.

Another study conducted by Hajar et al (2014) in Lestari (2020) utilizes activated sludge waste from the drinking water treatment of PDAM Pontianak City as an adsorbent of activated sludge containing Silicon Dioxide and Aluminum Oxide which can absorb 363,679 mg/g of iodine. According to $\mathrm{Al}$ in Fauziah (2019), he argues that Silica Dioxide can be good for adsorption and ion exchange, this is because of its high mechanical and thermal stability and is easily modified with certain chemical compounds to improve its performance and also that silica has wide and distinctive pores. So it is good for use as an ion absorber.

Meanwhile, research conducted by Lestari (2020) on the absorption of lead ions using adsorbents from activated sludge waste from drinking water treatment with variations in $\mathrm{pH}$, adsorbent mass and contact time on the concentration of lead ion absorption. The best results obtained are variations in the form of $\mathrm{pH} 5$, adsorbent mass of 0.2 grams, contact time of 45 minutes and adsorption capacity of 25.45 $\mathrm{mg} / \mathrm{g}$.

Based on previous research from the introduction above, it is necessary to conduct further research in order to determine the effect of variations in the $\mathrm{pH}$ of the solution of lead metal on activated sludge adsorbents for the absorption of lead metal with the aim of the study, namely to further manage waste that is of no value to be effectively used in adding value to waste. PDAM mud becomes

adsorbent by using a chemical activator, namely $\mathrm{KOH}$ solution so that the absorption of $\mathrm{Pb}$ ions obtained is maximized. The adsorption parameter used to see the variation of $\mathrm{pH}(3,4,5,6$ and 7$)$ in the lead ion solution mixture was characterized using Atomic Absorption Spectrometry (AAS).

\section{RESEARCH METHODS}

\section{Preparation of Tools and Materials}

Before the research will take place, the preparation of materials and tools is needed to facilitate the research process. The raw material in the form of waste sludge is taken from PDAM Tirta Musi, Poligon

$65 \mid$ The Effect Of V ariations Of Lead Metal Solutions On The Adsorbent Of Palembang Mud Waste Waste Tirta Musi Palembang 
Region and then processed into activated sludge. The tools used in the research process need to be prepared so that the research process will take place optimally. The equipment prepared in the form of a glass beaker, sieve, mortar, magnetic stirrer and stirrer were prepared.

\section{Preparation of PDAM Water Treatment Sludge Waste}

Samples of PDAM slurry are prepared and cleaned of rocks or gravel that are still in the mud to facilitate further processing. Weigh 150 grams of solid waste sludge samples were then washed with distilled water which is intended for the $\mathrm{pH}$ to be neutral and as well as the removal of impurities remaining in the waste and dried at $110^{\circ} \mathrm{C}$ for 24 hours until the sewage sludge water loss binding on sewage sludge taps. After drying, the mud is then pulverized using a mortar and sieved with a 100 mesh sieve until the waste sludge is included in the sample category with a size of 100 mesh. This is done to facilitate the contacting process of the activator.

\section{Mud Activation}

The 2M KOHG activator solution was prepared beforehand, then the fine sludge from the dry waste sludge preparation process was weighed as much as 100 grams and put into a glass beaker, added with the $\mathrm{KOH}$ activator solution that had been made earlier with a ratio of mud and $\mathrm{KOH}$ solution 1:2. Stirred for 3 hours at a speed of $120 \mathrm{rpm}$. The mixture in the form of a paste is then allowed to stand for 15 minutes then a layer is formed and separated between the mud and the activator solution, the activated sludge is then rinsed with distilled water until the $\mathrm{pH}$ becomes neutral. Dry the mud for 5 hours at a temperature of $120^{\circ} \mathrm{C}$ until it is completely dry and then sifted again until there are no lumps in the activated sludge to facilitate the absorption of lead metal ions.

\section{The effect of the adsorption of the mud adsorbent on the $\mathrm{pH}$ variation of the lead metal solution}

Before carrying out the contact process between the activated sludge and $\mathrm{Pb}$ ions. Make a mixed solution of $\mathrm{Pb}$ (II) ions with variations in $\mathrm{pH}$ from the lead solution $(3,4,5,6$, and 7). The parameter used is the variation of the $\mathrm{pH}$ of the lead solution which is contacted between the adsorbent and the metal solution. A total of $0.5 \mathrm{~g}$ of activated sludge sorbent was contacted with a $\mathrm{Pb}(\mathrm{II})$ ion solution with $50 \mathrm{~mL}$ of solution each. The $\mathrm{pH}$ variation was adjusted using $0.1 \mathrm{M} H \mathrm{HO} 3$ and $0.1 \mathrm{M} \mathrm{NaOH}$. The mixture was stirred at a speed of $120 \mathrm{rpm}$ and a time of 15 minutes. Variations in the $\mathrm{pH}$ of the solution were 3,4,5,6, and 7 to determine the optimum point of absorption of $\mathrm{Pb}$ metal ions on the activated sludge waste adsorbent from PDAM Tirta Musi. After knowing the value of lead concentration using atomic absorption spectrometry characteristics and the value of the concentration before and after absorption then calculating the absorption capacity of $\mathrm{Pb}(\mathrm{II})$ metal ions is calculated using the equation 


$$
\mathrm{Qe}=\frac{C o-C e}{m} \times \mathrm{V}
$$

With

Qe: The absorption capacity (mg / g)

Co: lead metal concentrations ( $\mathrm{mg} / \mathrm{L}$ )

Ce: Concentrations of lead at equilibrium (mg / L)

$\mathrm{V}$ : volume solution of metallic lead ( $\mathrm{ml})$

M: Mass adsorbent ( $\mathrm{g}$ )

\section{RESULTS AND DISCUSSION}

This research was carried out by looking at the effect of variations in $\mathrm{pH}$ on heavy metal solutions with an adsorbent in the form of activated sludge with raw materials from PDAM Tirta Musi Palembang mud with the preparation stage of activated sludge being washed, dried, mashed, and sieved using a sieve. 100 mesh size. Then it is activated to increase the surface area of the mud so that it can increase the adsorption capacity with $2 \mathrm{M} \mathrm{KOH}$ solution in a ratio of $2: 1$, hereinafter referred to as activated sludge. $\mathrm{KOH}$ is a strong alkaline solution that can increase the size of the pores in PDAM mud and can remove dirt that is still present in the sewage sludge. (Apriani in Lestari, 2020).

Then the activated sludge was used as an adsorber in a solution of $\mathrm{Pb}(\mathrm{NO} 3) 2$ with a concentration of $150 \mathrm{mg} / \mathrm{L}(150 \mathrm{ppm})$ which was varied according to the independent variables of the study. The use of a solution with a concentration of $150 \mathrm{mg} / \mathrm{L}$ refers to a previous study conducted by Intan Lestari in 2020 which conducted an experiment on adsorption of $\mathrm{Pb}$ (II) metal with PDAM Tirta Mayang Jambi mud at a solution concentration range of $10 \mathrm{mg}$. / $\mathrm{L}$ to $300 \mathrm{mg} / \mathrm{L}$. In addition, the use of solution concentration is based on the accuracy of the Atomic Absorption Spectrometry (AAS) tool used in analyzing the $\mathrm{Pb}$ content after the adsorption process. The results of the activation process of waste sludge into activated sludge with $\mathrm{KOH}$ solution activator can be seen in Figure 1.

67 | The Effect Of Variations Musi Palembang

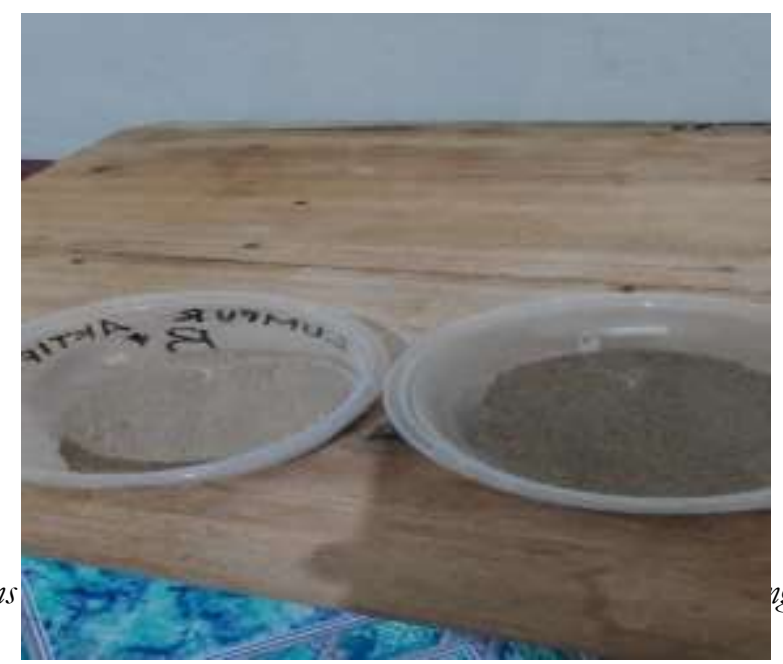


Figure 1. Activated Mud

From the activation results using $2 \mathrm{M} \mathrm{KOH}$ solution, the dried mud can then be contacted with lead metal solution. By varying the $\mathrm{pH}$ of the lead metal solution, which is

to see the effect of $\mathrm{pH}$ on the absorption of lead metal in the solution. The results of the analysis of the $\mathrm{Pb}$ (II) solution that were tested using Atomic Absorption Spectrometry (AAS) and varied based on the independent variables of the study which were then calculated Qe or absorption capacity are shown in

Figure 2 graph below:

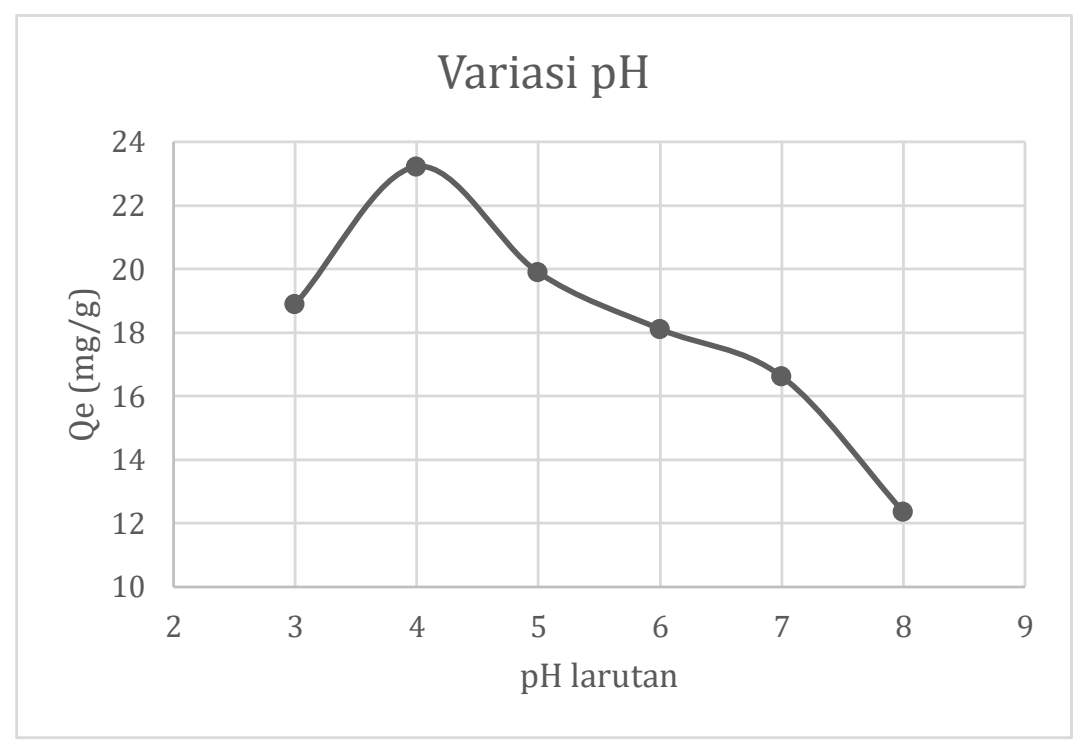

Figure 2. Graph of the Absorption Capacity of Lead Metal with Variations in Lead Solution pH

From Figure 2 it can be seen that the absorption at $\mathrm{pH}$ with a value of 3. 2020) where in acidic conditions the functional groups present will be positively charged so that there is a repulsion between the surface of the adsorbent and metal ions so that for $\mathrm{pH}$ which tends to be acidic it is relatively not absorbed much.Based on the explanation above, at low $\mathrm{pH}<4$ or acidic $\mathrm{pH}$ absorption of metal ions $\mathrm{Pb}(\mathrm{II})$ is relatively small, this can be caused by acidic conditions, the functional groups present in the adsorbent are protonated, resulting in ion binding. hydrogen $(\mathrm{H}+)$ and hydronium ions $(\mathrm{H} 3 \mathrm{O}+)$. In acidic conditions, the surface of the adsorbent is positively charged, there will be a repulsive force between the adsorbent surface and metal ions so that adsorption is low.

Good absorption variation is shown in the graph at $\mathrm{pH} 4$ with an absorption capacity value of 23.22 
$\mathrm{mg} / \mathrm{g}$. Meanwhile, at $\mathrm{pH}$ less than 4 and more than 4 the absorption decreased. Said (2008) explained that the adsorption process related to $\mathrm{pH}$ can be carried out in two models, namely adsorption through metal hydrolysis and adsorption through ion exchange.

At $\mathrm{pH} 4$ the adsorption is relatively high, this can occur because the metal hydroxide complex $(\mathrm{MOH}+)$ formed in the solution is greater than the $\mathrm{pH}$ of the more acidic solution, and the surface of the adsorbent will be negatively charged by releasing protons. so that through the electrostatic force there will be an attractive force. lead to increased adsorption. The removal of lead metal at low $\mathrm{pH}$ values will gradually increase with increasing $\mathrm{pH}$ values until it reaches $\mathrm{pH} 4$ (Mohammad, et al., 2015).

At $\mathrm{pH} 5$ and above the adsorption begins to decrease, this is because at that $\mathrm{pH}$ the metal ion $\mathrm{Pb}(\mathrm{II})$ begins to hydrolyze and the species $\mathrm{Pb}(\mathrm{OH}) 3$ - is formed. At high $\mathrm{pH}$ the surface of the adsorbent is negatively charged, resulting in a repulsion between the surface of the adsorbent and metal ion species, resulting in reduced adsorption.

At neutral or alkaline $\mathrm{pH}$, adsorption efficiency and absorption capacity tend to decrease, this is because $\mathrm{Pb}$ (II) can undergo a hydrolysis reaction in solution so that it is unstable and causes the ability of the activated sludge waste adsorbent to decrease to absorb $\mathrm{Pb}$ (II).

Under alkaline $\mathrm{pH}$ conditions, metal ions can form hydroxide deposits $(\mathrm{Pb}(\mathrm{OH}) 2)$ so that the adsorption process is difficult (Widayanto, 2017).

\section{CONCLUSION}

From the results of the study, it was concluded that the effect of variations in the $\mathrm{pH}$ of the lead metal solution on the adsorbent is very dependent on the $\mathrm{pH}$ value of the solution where in variations in $\mathrm{pH}$ there are differences in the absorption power of each $\mathrm{pH}$ solution seen from the linear graph, namely the optimum capacity is at $\mathrm{pH} 4$ with the value of absorption capacity (Qe) is $23.22 \mathrm{mg} / \mathrm{g}$.

\section{REFERENCES}

[1.] Said, NI 2008. Drinking Water Management Technology: Theory and Practice. Center for Environmental Technology. Jakarta.

[2.] Dabrowski, A. 2004. Adsorption-from Theory to Practice. Faculty of Chemistry, M. Curie. Skfodowska University. Poland.

[3.] Lestari, Intan et al. 2020. Absorption of Pb(II) Ions Using Adsorbents From Solid Waste Activated Sludge Drinking Water Treatment. Jambi University. Jambi

[4.] Hadi, P., Xu, M., Ning, H. \& Lin, CSK “A critical review on preparation, characterization and utilization of sludge-derived activated carbons for wastewater treatment”. Chemical Engineering Journal. 260, 895-906. 2015.

[5.] Pan, Z., Tian, J., Xu, G., Li, J. \& Li, G. "Characteristics of adsorbents made from biological, chemical and hybrid

69 | The Effect Of V ariations Of Lead Metal Solutions On The Adsorbent Of Palembang Mud Waste Waste Tirta Musi Palembang 
sludges and their effect on organics removal in wastewater treatment" Water Resource . 45, 819-827. 2011.

[6.] Widayatno, Tri, Teti Yuliawati. "Heavy Metal (Pb) Adsorption From Liquid Waste With Activated Bamboo Charcoal Adsorbent. University of Mubammadiyah Surakarta". J. Natural Materials Technology Vol. 1. 2017.

[7.] Mohammad, HS, B, AZ, Ali, Torabian and Mahdi, SS Removal Of Nitrate From Groundwater Using Activated Carbon Prepared From Rice Husk And Sludge Of Paper Industry Wastewater Treat. 2015.

[8.] Darmayanti et al, 2012. Adsorption of Lead (Pb) and Zinc (Zn) from the Solution Using Biocharcoal (Biocharcoal) Banana Kepok Peel Based on V ariations in pH. Tadulako University : Palu

[9.] Nenny, et al. 2013. Preliminary Study of Adsorbents from Solid W aste Activated Sludge Crumb Rubber Industry on Cr Metal Adsorption. Industrial Baristand Padang : Padang.

[10.] Widayatno et al. "Heavy Metal (Pb) Adsorption from Liquid Waste With Activated Bamboo Charcoal Adsorbent". J. Natural Material Technology. Vol. 1 No. 1. 2017.

[11.] Apriani, R., Faryuni, ID \& Wahyuni, D. "The effect of potassium bydroxide (KOH) activator concentration on the quality of durian peel activated carbon as an adsorbent of Fe metal in peat water". J. Prism Physics. Vol. 1 No.2 , 82-86. 2013.

[12.] Hajar, EW Effectiveness of Metal Adsorption $\mathrm{Pb}^{2+}$ and $\mathrm{Cd}^{2+}$ Using Chicken Egg Shell Adsorbent Media. J. Animal Sciences. Vol 1 No. 5, 1-7. 2016.

[13.] Hajar, S., Wahyuni, N. \& Destiarti, L. "Characterization of synthetic Zeolite A from PDAM Pontianak City mud and Alumina". Journal of Equatorial Chemistry. Vol 3 No. 1, 12-16. 2014.

[14.] al, P. e. "Synthesis and Characterization of Arginine Modified Sugarcane Bagasse Ash as an Adsorbent for Cu(II) Metal Ions". ALCHEMY Journal of Chemical Research. Vol 2 No. 14, 333-348. 2018. 